\title{
THE ART OF RURAL BUSINESS
}

\author{
NANCY WIMMER \\ microSOLAR \\ Vaterstetten, Germany \\ nw@microsolar.com
}

\begin{abstract}
Grameen Shakti has mastered the art of rural business. Sixteen years ago, the Bangladesh-based renewable energy company was a pioneer in an unexplored market. It had to learn its business from scratch, including how to market solar technology while finding ways to benefit local communities. This would take time, and so Shakti began its business with a plan to become sustainable. The company's later success-allowing five million people to benefit from light, electricity and additional incomedemonstrates what an entrepreneurial approach can achieve in a tough rural environment. It is not magic-what has evolved into a mature business model and is practiced in 1,500 field offices throughout Bangladesh can be studied and learned. It involves financing a low-income clientele, training, reliable service, and above all, innovation and hard work. At its root, Shakti's business is about making the economy work for everyone, including the people at the bottom of the pyramid.
\end{abstract}

Acknowledgements. The author thanks the publisher MCRE Verlag for the kind permission to reprint parts of the book Green Energy for a Billion Poor.

\section{THE ART OF RURAL BUSINESS}

The move to explore alternatives to grid electricity in Bangladesh was an initiative of the Grameen Bank, which by 1994 had over two million borrowers in 34,000 villages. Twenty years of Grameen Bank experience had demonstrated that the rural poor can successfully start small businesses with the help of tiny loans (microcredit), but many of these businesses need electricity to prosper. 
To support home businesses, the bank introduced housing loans in 1984 to provide a safe dry space to work in year round, but the problem of working after dusk by the dim light of an open flame remained. A decade later, only nine percent of rural households nationwide were connected to the grid. Moreover, the grid expanded so slowly that young villagers had little chance of experiencing electricity during their lifetimes. Grameen Shakti was founded as a rural energy business to solve this problem.

The World Bank, the United Nations, governments, and development organizations considered renewable energy a strategic means of development, but when Grameen Shakti was founded in 1996, the renewable energy movement had not yet reached Bangladesh. Renewable energy in rural areas then was often a field of short-run projects, failed experiments and feasibility studies. Grameen Shakti, which literally translates to rural energy, would take a different approach. It was founded as a company to create a market for renewable energy technologies for the people in rural Bangladesh.

Shakti made solar home systems-a decentralized form of power supply best suited to rural households-the focus of its renewable energy business. While solar home system technology is sophisticated, the installation of the solar panel, battery, and charge controller is essentially "plug and play," and basic maintenance can be quickly mastered. International suppliers of solar systems offered support along with initial training and technical assistance to help the young company get started. It thus made sense for Shakti to first build its business on solar-powered systems for direct current (DC) appliances.

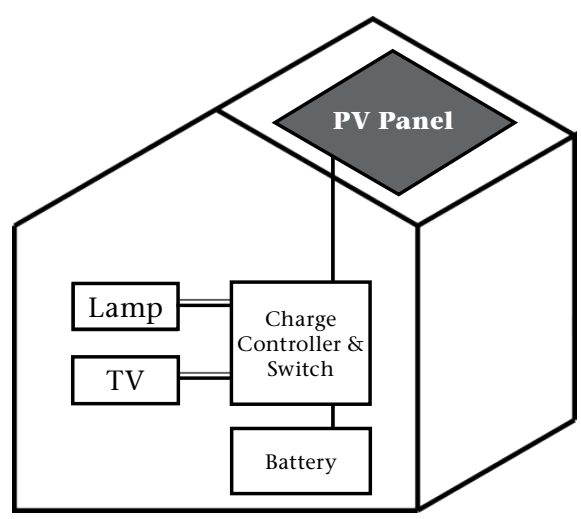

Figure 1. Main components of a solar home system (SHS)

As a newly founded company, Shakti was challenged to find out how to run a solar business in a rural environment. As important as Grameen 
Bank's support was at the start, microcredit was an altogether different business compared to marketing a technical product. Village people understood loans, but not solar power. They were aware of their need for electricity, but thought it could only come from diesel generators and the grid. Renewable sources of power were exotic. A unique business model, therefore, had to be developed in order to reach a population that was skeptical of a technology that seemed like magic since its power came from the sun.

Shakti managers thus attended international seminars, talked with energy experts, and evaluated case studies in the hope of learning more about running a solar company. However, what they learned seemed lunar in its usefulness for rural business. The more the managers heard about conventional ways of doing solar business, the more they thought that they were not in the same business at all.

Shakti was doing something different. It was learning directly from its potential customers in the villages. Its approach was bottom-up, trial and error, open to new information and experiences. It was an experiment with no desire to become a theory. When Shakti discovered what best suited one villager's needs, the company tried it on a few dozen people, then a few hundred, and then fine-tuned the process until it ran smoothly. As a pioneer in an unexplored market, Shakti focused on creating a product people would enjoy-something that would pique their curiosity and create excitement in the village.

Focusing first on how people could benefit from solar power, Shakti learned that children's studies at night were a top priority for mothers. Further probing revealed other concerns: from a sawmill owner about how dangerous it was to work after dark, from an electrician about his problems with a kerosene cooker to heat up his soldering iron, and, best of all, about how a grocery shop owner and a carpenter earned extra money on the side by renting solar lamps to neighbors.

Learning from its village customers, however, was only one of Shakti's challenges. The prohibitive cost of a solar home system was a major problem for the start-up rural energy company. For the 13,000 Taka (US\$317) a 17W solar home system cost in 1996, many villagers could have bought three months' worth of food for their families. A Grameen Bank loan averaged US $\$ 100$ to start a small business, not enough for Grameen borrowers to become Shakti's customers. The start-up company had to do business with customers who lacked steady incomes, bank accounts, telephones, and insurance against illness, floods and storms. True, there was no solar competition for Shakti in rural Bangladesh, but 
there was no market either. Shakti was thus challenged to find unconventional solutions.

Rural business takes time. Shakti had learned this from the Grameen Bank experience, and for this reason it was a company built to last. Shakti had to set up a network of village branches, staff a new company, master a new technology, and expand slowly in the beginning until it understood the market. It started not as a project but as a business with a market-based approach and a focus on becoming sustainable. Experts warned that any such business approach was doomed to fail since photovoltaic technology was far too expensive and sophisticated to suit a low income and poorly educated rural clientele. In some ways, the critics were right.

\section{Working at the Cutting Edge of Business}

"You can't do healthy business in a sick society," the business philosopher Peter Drucker never tired of saying (Drucker, 2008). He could have had business in poor rural societies in mind. As a rural energy company, Grameen Shakti works by necessity in underdeveloped rural communities. But its business is limited to those who can afford a solar system-millions cannot. In time, Shakti was able to offer its customers easy credit terms which changed things for the better, but the challenge remains: How does one do business with the many poor? How does one work at the cutting edge of rural business?

If money alone was the solution, villagers in Bangladesh would not have had to wait until the $21^{\text {st }}$ century for solar power. But money alone creates neither entrepreneurs nor trust nor innovation, which are the prerequisites for progress in rural business. To this day, there is no simple answer to these concerns, no easy solution, no silver bullet. Shakti takes many approaches to advance its business: it experiments, succeeds, and fails. It strives to keep prices low, streamlines the organization, and exploits technological advancement. But Shakti knows that in the long run, its business is determined by village society; the healthier the rural community, the better the business, the more people benefit.

What Shakti's critics did not understand was the power of innovation to open up opportunities in an undeveloped market. True, no one can work miracles in a traditional rural society, but entrepreneurship, increased income and social innovation can make a difference. The following illustrates in brief what this means in practice. The need for entrepreneurial companies in a tough rural market is demonstrated, and 
the assumption that the success of rural business in the long run depends on innovating ways to advance village communities is introduced.

\section{Entrepreneurs Become a Hallmark of Shakti}

Shakti began exploring the rural market by hiring young engineers to venture out into the hinterland and set up its first village branches. They proved to be ingenious in mastering a new technology and convincing village leaders and people of influence to invest in solar systems. This helped popularize solar power, but still, only a few villagers could afford it. This, however, changed for the better when Shakti later introduced customer financing with one to three years to repay. The engineers also directed their energies toward the small businesses that abound in rural areas. They lost no time instructing barbers, tailors, carpenters, and the owners of grocery shops, pharmacies, and bicycle repair shops how they could increase their profits by working longer hours with the benefit of solar electricity.

Branch engineers sat down with each of their potential customers and calculated a) how much extra income they could earn per month, and b) how many months it would take for them to pay for the solar system. They discussed how much power was necessary given how many lamps, appliances and outlets a customer had. They also visited their customers monthly in order to service the systems and make sure their investments paid off.

News of increased income with solar power spread fast, and soon villagers were approaching Shakti engineers with surprisingly good business ideas. One example was that of a travelling food vendor and his grocery cart. His idea was to place a solar panel on top of his cart in order to power a lamp and cassette player as he cycled through the villages. "When people hear popular Bangla songs they all gather around my cart to enjoy the music," he told the branch engineers. "They buy tea and sweets. With bright solar light and music I can sell food until midnight."

"We didn't have to teach him anything about his business," recalled the branch manager. "All we did was calculate that he could afford a $25 \mathrm{~W}$ solar system for 310 Taka a month and still make a profit."

One major problem still persisted, however: even with additional working hours, many businesses were too small to generate enough profit to afford a solar home system. In response to this, Shakti began experimenting with a micro-utility model in village bazaars whereby 
one shopkeeper buys a solar system and then shares the electricity it produces with neighboring shops for a small fee. This gives the owner of the solar system the advantage of added income and provides his or her neighbors with cheap access to solar electricity. Shakti, however, would not make micro-utilities part of its business until it had worked out a special financing model and tested it at different branches. One example of such a test is the case of Mr. Gazi, one of thousands of entrepreneurs who own a solar system. Typical for rural Bangladesh, he runs a small shop at a village market and earns a modest monthly income of about 5,000 Taka; not typical is that he can afford a 50W solar system for five times more than what he earns in a month.

\section{The Solar Energy Entrepreneur}

Mr. Gazi can afford the solar system because he earns money using it. In addition to selling groceries at the market, he is a small-scale energy service provider, a micro-utility, serving a clientele of three. His solar system powers four lamps, but he uses only one to light his shop. He rents the other three lamps to his neighbors, shop owners like himself. All four benefit from solar electricity. Mr. Gazi profits from the monthly rental fees and Shakti's special credit terms for micro-utility owners: only 10\% down payment, no service charge, extended repayment period to three and a half years, and ongoing technical support from a nearby Shakti branch. In addition to this, Shakti provided one solar lamp for half the price to help Mr. Gazi get started.

Shakti now provides training, financing, and technology to more than 20,000 micro-utility entrepreneurs, reaching low-income villagers like Mr. Gazi who otherwise could not afford a solar system. Everyone benefits, and the company learned about a new sector of the market from its low-income customers. For example, what these entrepreneurs feared most was the risk of a micro-utility business: What if it fails and they are stuck with paying off an expensive solar system?

The thousands of micro-utilities now in operation are run by shopkeepers and private households, as well as cattle and poultry farmers who invested in biogas. The micro-utility model, therefore, varies for low-income shop owners like Mr. Gazi and for better-off poultry farmers who can afford a biogas plant. Shakti's flexible customer financing and reliable service, however, remain constant. Most of all, micro-utility entrepreneurs signify Shakti's determination to succeed in a low-margin sector of the market in order to help rural communities thrive. Microutilities work because Shakti shoulders some of the risk by keeping the system operational, training the micro-utility owner free of cost, and 
helping customers avoid repayment problems. If necessary, Shakti takes the solar system back.

\section{The Biogas Entrepreneur}

"When introducing a new product, we need customers to demonstrate its benefits," an experienced branch engineer explains. "Let people see the technology, touch it, talk about it at the market. Let them discuss with biogas pioneers and hear firsthand from customers like Mr. Maola why he has invested in his third biogas plant."

Mr. Maola raises 3,000 chickens on his farm near the Dhaka airport. When you talk to him, you sense at once that he is an entrepreneur with heart and soul. He quickly recognized the market opportunity for a biogas micro-utility near Dhaka. Liquefied petroleum gas (LPG) for cooking fuel cost him 1,800 Taka a month in addition to the 1,000 Taka he was paying for firewood. Moreover, a biogas plant could also be put to good use for what usually just cost him money to remove: the huge amount of dung produced by his 3,000 chickens.

Mr. Maola first invested in a $6 \mathrm{~m}^{3}$ plant and easily found biogas customers in the densely populated area outside Dhaka. Shakti technicians laid the pipes to connect with neighboring houses and civil engineers were on hand for technical assistance. Everything worked out better than expected, and soon more neighbors than Mr. Maola could accommodate wanted biogas. He invested in a second $6 \mathrm{~m}^{3}$ plant and later in a third $\left(4.8 \mathrm{~m}^{3}\right)$. His plants now supply twenty-three families with biogas, generating an income of 8,050 Taka per month (his average monthly income prior to investing in biogas was 10,000-12,000 Taka). He has full ownership of two biogas plants and will finance the third in less than two years with a loan from Shakti.

Like thousands of other micro-utility owners, Mr. Maola is a local entrepreneur. The biogas plants digest local resources. The gas produced sells locally, which helps both the entrepreneurs and their village customers save on wood and imported kerosene. Local technicians and masons earn money by building and maintaining the biogas plants, and Shakti trains local technicians for its branches. The money they earn stays in their villages, helping them thrive.

Undeveloped communities are full of hidden opportunities to create wealth for their villages, but they need an entrepreneurial company to figure out how to turn these into business opportunities so villagers can benefit. 
Mr. Khaledur, for example, showed little interest in a biogas microutility since neighboring houses were too far away. Instead, what piqued the cattle farmer's curiosity was how he could become a supplier of organic fertilizer. The branch engineer calculated that his biogas plant could yield about 20,000 Taka worth of bio slurry per year. It was a promising business opportunity for a farmer who was fattening thirty oxen for the upcoming Eid festival, and also for Shakti's newly developed organic fertilizer, Jaibo Shar. Farmers in Bangladesh are increasingly dependent on imported chemical fertilizer. Thus, if bio slurry is marketed successfully, farmers could profit from an abundant supply at local markets, and biogas owners like Khaledur, from a new source of income. The fertilizer business further adds to the village economy because the production, collection, and refinement of bio slurry create local jobs.

None of these businesses are easy to implement. None are as simple as the above examples make them sound. Shakti's organic fertilizer required months of testing against chemical fertilizer and a government license to market it commercially. Shakti had to hire agricultural experts for quality control and find ways to dry, package and distribute bio slurry for local markets. Biogas technology had a 30 year history of problems on the delta. Plant construction for Shakti's underground model takes fifteen to twenty days, and earthwork is often impossible during monsoon rains, for groundwater or sediments can enter the plant, causing problems. Finally, when cattle die or farms are sold, the plant cannot be moved to a new location.

Businesses with improved cook stoves were no easier. Shakti introduced the stoves in 2006 to improve health conditions in village kitchens, but it took four years of stove redesign and convincing the cooks before they accepted a stove different from their traditional chula. For one, Shakti's training program for local technicians to construct the stoves failed: the first stove models were too difficult for villagers to build, and were problematic during seasonal flooding. Engineers went back to the drawing board, but Shakti persevered.

In 2010, Shakti's engineers designed an improved cook stove which came ready-made from one of the company's 200 stove factories and could be marketed by Shakti-trained women entrepreneurs. Within a year of launching the new model, Shakti increased stove installations fourfold. In the same year, Shakti also (and finally) received the government license to market Jaibo Shar, and is now training entrepreneurs to take it to market. Finally, to improve business for biogas entrepreneurs, Shakti launched a pilot project with portable biogas plants made of fiberglass which could be installed in two to three hours, even during the rainy season. 
The entrepreneurs described above are more than simply random examples of small-time village dealers in stoves, biogas or electricity. They are early role models of a new class of rural energy entrepreneurs. They require risk on the part of Shakti and an extra effort to cultivate. Were Shakti out for short-term profit, it would hardly cater to them. Shakti, however, believes that there will be many entrepreneurs in the future and that in the long term, they will be the ones to grow the market.

\section{Turning Villages into Manufacturing Hubs}

When international donors predicted in 2005 that the potential market for solar home systems, biogas plants and cook stoves could be in the millions in Bangladesh (Grameen Shakti, 2005), Shakti had installed fewer than 60,000 solar systems, 30 biogas plants, and had not yet launched its stove program. These numbers, however, are misleading. Shakti had an ambitious program and was already planning for major growth: 130,000 installed solar systems by 2007 , for example. What concerned the company as early as 2005 was who would do what was necessary to develop the rural market-the installations, maintenance, and marketing.

Shakti is a $100 \%$ service company-from installation and maintenance to financing, training and repair. This pays off in the long-run, but only if you have enough trained staff to do the job. Moreover, Shakti works in a country with more navigable waterways than (bad) roads, and thus logistics are a nightmare. To keep its branches stocked, all system components have to be transported from the capital, Dhaka, to hundreds of branch offices throughout Bangladesh. Shakti thus responded to the challenge with a plan to set up village technology centers for local production of solar home system accessories.

The Grameen Technology Centers, as they are called, are Shakti's boldest innovation. They are managed by women engineers, who, like their male colleagues, live, work and train in rural communities. Like everything else in rural business, the centers will take time to staff and develop, especially because it is not common in Muslim society for young, unmarried women to live and work in villages far away from their families. Shakti first set up five pilot technology centers in different parts of rural Bangladesh. Each was staffed with three women engineers to manage all local production and repair of lamps, mobile phone chargers, DC-DC converters, and charge controllers.

How these centers developed into village manufacturing hubs was exciting enough to fill an entire chapter in my book, Green Energy for a 
Billion Poor (Wimmer, 2012). Of importance in this article is how these technology centers function as incubators for a further innovation: the village energy entrepreneur. The production units also function as training centers for village women and thus advance energy entrepreneurship far beyond the micro-utility approach. The candidates for this training are unemployed women between the ages of eighteen and thirty with at least eight years of schooling, with preference for women who are either widowed or divorced-women like 23-year old Sayma and 18year old Bhulana, for example. Both trained at a Grameen Technology Center to become energy entrepreneurs, are self-employed, and earn an income producing solar accessories. With the help of a branch technician, Sayma also learned to install solar systems for extra income; both young women do minor solar repairs for friends and neighbors. Shakti pays the entrepreneurs according to what they produce and helps them build their customer base by providing a signboard in front of their houses for everyone to see, announcing that they are "Solar Technicians Certified by Grameen Shakti."

Sayma has become a successful freelance technician and pays two of her friends to help her increase production. She earns up to 7,000 Taka a month, deposits 1,000 Taka of her income in her savings account and gives ca. 5,000 Taka to her mother for family expenses. Bhulana, divorced and with a 5-year old son, likewise contributes on average of 5,000 Taka per month to her family's income, which is as much as her father earns in a good month selling ice to fishermen. In an unpredictable rural environment, this is a substantial increase in monthly income for poor families, many of whom depend on one male earner.

Seven years after the village technology centers were launched, they are turning into solar manufacturing hubs. Forty-six technology centers guarantee a continuous supply of solar system components to over 1,000 branches. By 2010, branches were installing 20,000 solar systems a month; by 2012, 1,000 systems a day, and none of which would have been possible without local production and energy entrepreneurs.

The demanding task of keeping the branches supplied also shifted from the head office in Dhaka to the field. Branch managers inform divisional managers of their product needs for the upcoming month, and the divisional managers coordinate the supply from the technology centers. But it is the women engineers who keep everything on schedule, do quality control, and prevent breakdowns in the supply chain. They travel to the villages, train the novices, and motivate the freelance technicians. "My division has 400 energy entrepreneurs working at home, at the technology centers and in their villages doing solar system mainte- 
nance," explains a divisional manager. "That the women engineers can coordinate all of this is an art. But it actually works."

In the future, Grameen Shakti's technology centers will be at the forefront of the company's organizational development. For instance, in November 2012, one of the world's leading electronics companies agreed to train Shakti engineers to produce its advanced charge controllers and other electronic equipment. There is no doubt that much still lies ahead for Shakti's technology centers and its young women entrepreneurs. They will bring down the cost of products and services and lay the foundation for growth for a market that will absorb millions of solar systems, cook stoves, and biogas plants. True, only a few hundred of these small entrepreneurs earn enough to feed a family. But it is a start. Village customers trust their expertise, and branch engineers are relieved that they can share their growing workload with entrepreneurs like Sayma and Bhulana.

\section{The Art of Rural Business}

"Why is it when development professionals think about the poor and disadvantaged, the best they can come up with is a handout? Poor people are entrepreneurial, otherwise they couldn't survive" (Muhammad Yunus, 1990). Muhammad Yunus often posed this question to experts when the Grameen Bank was still in its infancy, and when microcredit to the poor for small businesses was an exotic approach to development. To this day, people often see the poor as passive victims of poverty, disorganized, uneducated and undisciplined. The reality is that they have learned to be enterprising and flexible enough to survive in a tough rural environment. Sporadic incomes force them to actively manage their lives in order to keep food on the table and survive the uncertainties of rural life.

It is therefore typical for rural people to have more than one source of income, even if they earn moderate incomes and are government employed. Teachers do private tutoring, and own grocery shops and pharmacies at the market for evening business; farmers earn additional income as part-time tailors and carpenters, and do doctoring on the side. Some do better than others, some make better choices, but they all work in an unpredictable rural environment. It sometimes takes only a tiny blow to send them into a downward spiral: a bad harvest, an accident, an illness.

Rural life is unpredictable, and yet millions of villagers have benefited, within their lifetimes, from Grameen's innovations in banking 
and renewable energy. But what we so often hear is that villagers in developing countries are too poor and too difficult to serve. Perhaps, then, we must train our minds to see the elephant in the room and ask: If this is so impossible, how is it that the Grameen Bank has 8 million borrowers and Shakti has succeeded in installing one million solar systems in poor rural communities? Part of the answer lies in the fact that the bank and Shakti offer reliable services people can depend on. Shakti has 11,500 trained engineers and technicians in the field who guarantee service to their village customers even in times of disaster. They live, work and train in the villages, become part of the fabric of rural life, and understand the rural environment.

More fundamental to understanding Grameen's success is the philosophy which guides its business. Both companies view village people as creative and entrepreneurial with the potential and the will to improve their quality of life, and there is where they need Grameen's help. Women, for example, may have the right to own property, but they depend on the social structure of the family to use this right. For this reason, the bank grants a housing loan to a woman borrower only if the title of the land and the house are in her name. No deed, no loan. Shakti promotes poor women as freelance entrepreneurs by shouldering part of their risk, by financing them, and by providing equipment and know-how.

Improving the quality of villagers' lives, therefore, is not simply about increasing their incomes and bringing wealth to the village, but about enhancing people's ability to help themselves and gain control over their lives. Similarly, the economist and philosopher Amartya Sen sees both the process and the outcome of development as increasing freedom and control over one's life: "The quality of our lives should be measured by our freedom, not by our wealth and income" (Sen, 1999). Education, income and health are therefore aspects of freedom because of what they allow human beings to achieve. This is Shakti's motivation for enabling poor woman divorcees and school-dropouts to take part in the life of the community and enjoy self-respect as certified solar technicians. Neighbors say to Sayma's mother, "Oh, I hear your daughter works with electronics." That villagers trust her expertise and bring her lamps to repair means as much to her as an income.

What looks like a simple concept for creating rural energy entrepreneurs turns out to be a fine-tuned approach in practice, one that reveals prominent features of the art of rural business: the spirit to create business in unconventional ways, the attitude to treat rural people as resourceful entrepreneurs, the intention to do business anywhere, and the deep conviction that rural people can make an income and lead a better life. 


\section{REFERENCES}

Drucker, P. F. 2008. The essential Drucker. New York: Collins Business Essentials.

Grameen Shakti. 2005. Company internal status report. Dhaka, Bangladesh (unpublished / private communication)

Muhammad Yunus. 1990. Grameen Bank Dialogue Program, Grameen Trust. Dhaka, Bangladesh.

Sen, A. 1999. Development as freedom. Oxford: Oxford University Press.

Wimmer, N. 2012. Green energy for a billion poor: How Grameen Shakti created a winning model for social business. Vaterstetten: MCRE Verlag. 